\title{
Phage Ø29 Protein p6 Is in a Monomer-Dimer Equilibrium That Shifts to Higher Association States at the Millimolar Concentrations Found in $\mathrm{Vivo}^{\dagger}$
}

\author{
A. M. Abril,,${ }^{\ddagger}$ M. Salas, ${ }^{*}$, J. M. Andreu, ${ }^{\S}$ J. M. Hermoso, ${ }^{\ddagger}$ and G. Rivas ${ }^{\S}$ \\ Centro de Biología Molecular "Severo Ochoa" (CSIC-UAM), Universidad Autónoma, Cantoblanco, 28049 Madrid, Spain, and \\ Centro de Investigaciones Biológicas (CSIC), Velázquez, 144, 28006 Madrid, Spain
}

Received April 29, 1997; Revised Manuscript Received July 23, $1997^{\otimes}$

\begin{abstract}
Protein p6 from Bacillus subtilis phage $\varnothing 29\left(M_{\mathrm{r}}=11800\right)$ binds in vitro to DNA forming a large nucleoprotein complex in which the DNA wraps a multimeric protein core. The high intracellular abundance of protein $\mathrm{p} 6$ together with its ability to bind the whole Ø29 DNA in vitro strongly suggests that it plays a role in viral genome organization. We have determined by sedimentation equilibrium analysis that protein $\mathrm{p} 6(1-100 \mu \mathrm{M}$ range $)$, in the absence of DNA, is in a monomer-dimer equilibrium, with an association constant $\left(K_{2}\right)$ of $\sim 2 \times 10^{5} \mathrm{M}^{-1}$. The intracellular concentration of protein $\mathrm{p} 6(\sim 1$ $\mathrm{mM})$ was estimated measuring the number of copies per cell $\left(7 \times 10^{5}\right)$ and the cell volume $\left(1 \times 10^{-15}\right.$ $\mathrm{L}$ ). At concentrations around $1 \mathrm{mM}$, protein $\mathrm{p} 6$ associates into oligomers. This self-association behavior is compatible with a dimer-hexamer model $\left(K_{2,6}=3.2 \times 10^{8} \mathrm{M}^{-2}\right)$ or with an isodesmic association of the dimer $\left(K=950 \mathrm{M}^{-1}\right)$, because the apparent weight-average molecular mass $\left(M_{\mathrm{w}, \mathrm{a}}\right)$ does not reach saturation at the highest protein concentrations. The sedimentation coefficients of protein $\mathrm{p} 6$ monomer and dimer were 1.4 and 2.0, respectively, compatible with translational frictional ratios $\left(f / f_{\mathrm{o}}\right)$ of 1.15 and 1.30 , which slightly deviate from the hydrodynamics of a rigid globular protein. Taking together these results and considering the structure of the nucleoprotein complex, we speculate that the observed oligomers of protein p6 could mimic a scaffold on which DNA folds to form the nucleoprotein complex in vivo.
\end{abstract}

The genomes of prokaryotic organisms are organized in higher order nucleoprotein complexes that, besides a packaging role, mediate fundamental processes of DNA such as replication, transcription, recombination, and transposition (Echols, 1990). Some of these complexes are assembled by architectural elements that by analogy to eukaryotic systems are referred to as histone-like proteins. In Escherichia coli, the major constituents of bacterial nucleoid are the HU heterodimer [reviewed in Drlica and Rouviere-Yaniv (1987)] and H-NS [reviewed in Ussery et al. (1994) and Atlung and Ingmer (1997)]. These proteins are small, very abundant, and bind DNA with little or no sequence specificity, usually through the minor groove. The pleiotropic nature of mutations in their corresponding genes indicates that these proteins have multiple functions. HU is reported to be involved in replication, transposition, and transcriptional control, while H-NS has been suggested to be a modulator of regulated gene expression.

Protein p6 from Bacillus subtilis phage $\varnothing 29$ has some features resembling those expected for a histone-like protein. Protein p6 is the most abundant protein in Ø29-infected cells and binds in vitro to the viral DNA forming multiple complexes spread virtually throughout the entire genome,

$\dagger$ This work was supported in part by NIH Grant 5R01 GM2724217 (MS), Dirección General de Investigación Científica y Técnica, Grants PB93/0173 (MS), PB95/0116 (JMA) and PB95/0120 (GR), EU Grant CHRX-CT92-0010 (MS), Ayuda Especial del CSIC (Estructura y Función de Proteínas) and the institutional help of the Fundación Ramón Areces to Centro de Biología Molecular "Severo Ochoa".

* Address correspondence to this author.

* Universidad Autónoma.

$\$$ Centro de Investigaciones Biológicas.

${ }^{\otimes}$ Abstract published in Advance ACS Abstracts, September 15, 1997.

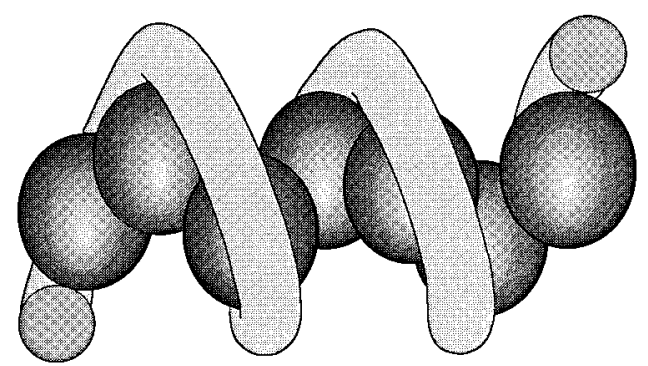

FIGURE 1: Model of protein p6-DNA complex. The path of the DNA in the complex is described in Serrano et al. (1993): one superhelical turn has $63 \mathrm{bp}$ and every protein p6 dimer, represented by ellipsoids, is bound to $24 \mathrm{bp}$. The DNA in the complex is strongly bent $\left(66^{\circ}\right.$ every $\left.12 \mathrm{bp}\right)$, undertwisted ( $11.5 \mathrm{bp}$ per turn) and highly compacted (4.2-fold).

of sizes ranging from $\sim 100$ base pairs (bp) up to $\sim 2$ kilobases (kb) (Gutiérrez et al., 1994). Protein p6 binds to DNA through the minor groove, and it does not recognize a specific sequence, but rather a DNA structural feature such as bendability (Serrano et al., 1989). In the nucleoprotein complex, the DNA adopts a right-handed toroidal conformation winding a multimeric protein core (Serrano et al., 1993) (see Figure 1). Therefore, complexed DNA has a high degree of compaction and it is strongly distorted. The formation of nucleoprotein complexes at the origins of replication activates the initiation of $\varnothing 29$ DNA replication in vitro (Serrano et al., 1989), and indeed protein $\mathrm{p} 6$ is absolutely required for viral DNA synthesis in vivo (Carrascosa et al., 1976). In addition, protein $\mathrm{p} 6$ also represses transcription from $\emptyset 29$ early promoter $\mathrm{C} 2$ both in vivo and in vitro (Whiteley et al., 1986; Barthelemy et al., 1989). 
Footprinting studies of the protein p6-DNA complex showed a repeating binding pattern of protein dimers (Serrano et al., 1990), and in fact, protein p6 formed dimers in solution (Pastrana et al., 1985). Fluorescence studies have shown that protein p6 binding to DNA is highly cooperative (A. M. Abril, unpublished results); thus, presumably, the complex is propagated by dimer-dimer interaction. In the present study, we have characterized the state of association of protein $\mathrm{p} 6$ by sedimentation equilibrium, as a function of temperature, ionic strength, and protein concentration. We have also addressed the question whether the in vivo amount of protein p6 suffices to complex all the DNA of the viral progeny by quantification of the intracellular amounts of protein p6 and Ø29 DNA, and studied the self-association behavior of protein p6 at concentrations approaching the in vivo conditions. Furthermore, global hydrodynamic properties of the protein were obtained at different states of association by means of sedimentation velocity, from which a gross shape of the protein $\mathrm{p} 6$ species can be derived.

\section{MATERIALS AND METHODS}

Determination of the in Vivo Concentration of Protein p6. B. subtilis 110NA (try ${ }^{-}$spo $A^{-} s u^{-}$) (Moreno et al., 1974) cells were grown at $30^{\circ} \mathrm{C}$ in $\mathrm{LB}$ medium supplemented with $5 \mathrm{mM} \mathrm{MgSO}_{4}$ to $0.45 \mathrm{OD}_{550}$ and then infected with Ø29 sus 14(1242) mutant phage (delayed lysis phenotype) at a multiplicity of infection of 4 . Aliquots were taken at different times after 5 min of adsorption for determination of the number of cells and their volume, phage development and the amount of $\varnothing 29$ DNA and protein p6. The number and volume of cells was measured in a Coulter Counter model ZM. In addition, B. subtilis cells, previously fixed in $0.1 \%(\mathrm{v} / \mathrm{v})$ formaldehyde, were observed with an Olympus System Microscope model BHS and photographed with an Olympus Photomicrographic System model PM-10AD. The volume of cells harvested $90 \mathrm{~min}$ after infection was also calculated directly from the photographs (about 600 measurements), taking into account the magnification factor and assuming an ellipsoidal shape. Intracellular phage development was followed by plating on B. subtilis MO-101-P ( $t h r^{-}$ spo $\mathrm{A}^{-} s u^{+44}$ ) (Mellado et al., 1976) after treatment with lysozyme $(500 \mu \mathrm{g} / \mathrm{mL})$. The amount of $\varnothing 29$ DNA was determined by electrophoresis as reported by Bravo et al. (1994), and the corresponding bands were quantified by densitometry in a Molecular Dynamic 300A densitometer using purified $\varnothing 29$ DNA as standard. The amount of protein p6 was determined by two-dimensional gel electrophoresis, performed as previously described in Santarén et al. (1993). Cultures were concentrated 20-fold in lysis buffer $(9.8 \mathrm{M}$ urea, 2\% ampholytes, pH 7-9, 4\% NP-40 and $100 \mathrm{mM}$ dithiothreitol), loaded on gels that, after electrophoresis, were stained with Coomassie blue. Protein p6 was quantified by densitometry as above, using as standard purified protein p6.

Sedimentation Equilibrium. The experiments were performed in a Beckman Optima XL-A analytical ultracentrifuge equipped with absorbance optics, using an An60Ti rotor. Protein p6 was equilibrated in buffer A $(50 \mathrm{mM}$ Tris- $\mathrm{HCl}$, $\mathrm{pH} 7.5$, and $10 \mathrm{mM} \mathrm{MgCl}_{2}$ ) with $50 \mathrm{mM} \mathrm{NaCl}$ unless otherwise stated. Short column experiments $(60-80 \mu \mathrm{L}$ of protein $\mathrm{p} 6$, loading concentration ranging between $2 \mu \mathrm{M}$ and $0.7 \mathrm{mM})$ were done at different speeds $(15,20,25$, and 30 krpm) by taking absorbance scans $(0.001 \mathrm{~cm}$ step size, $4-10$ averages) at the appropriate wavelength $(230,250,280$, or $290 \mathrm{~nm})$ at sedimentation equilibrium. We used standard (12 $\mathrm{mm}$ optical path) double-sector or six-channel centerpieces of charcoal-filled Epon, with the exception of the experiments at the highest loading protein concentrations, where $4 \mathrm{~mm}$ double-sector centerpieces were employed, at scanning wavelengths between 280 and $300 \mathrm{~nm}$. The equilibrium temperature was $20^{\circ} \mathrm{C}$, except otherwise indicated. In all the cases, high-speed sedimentation (42 krpm) was conducted afterward for baseline correction.

Whole-cell apparent weight-average molecular masses $\left(M_{\mathrm{w}, \mathrm{a}}^{\mathrm{c}}\right)$ were determined by fitting a sedimentation equilibrium model for a single sedimenting solute to individual datasets with the programs XLAEQ and EQASSOC [supplied by Beckman; see Minton (1994)]. The partial specific volume of protein p6 was $0.728 \mathrm{~mL} / \mathrm{g}$, calculated from the amino acid composition of the protein deduced from the gene 6 sequence (Murray \& Rabinovitz, 1982) and, when necessary, corrected for temperature according to Laue et al. (1992). Several procedures were used to determine the selfassociation behavior of protein p6. (i) A monomer-dimer association model at sedimentation equilibrium was globally fitted to multiple experimental data using either the MicroCal-Origin version of NONLIN (Johnson et al., 1981) or the conservation of signal algorithm [MULTEQ1B and MULTEQ3B programs, see Minton (1994)]. This procedure was used at protein p6 concentrations below $0.1 \mathrm{mM}$. The monomer relative molecular mass was taken as 11800 and a value of $8380 \mathrm{M}^{-1} \mathrm{~cm}^{-1}$ was used for the extinction coefficient of protein p6 at $280 \mathrm{~nm}$ (Perkins, 1986). (ii) When the whole set of experimental data was considered, models for self-association (Chatelier \& Minton, 1987; Muramatsu \& Minton, 1989) were fitted to secondary data (apparent weight-average molecular mass, $M_{\mathrm{w}, \mathrm{a}}$, versus protein concentration) using a nonlinear least-squares method.

Sedimentation Velocity. The experiments were carried out at $60 \mathrm{krpm}$ and $20^{\circ} \mathrm{C}$ in the same XL-A instrument. Protein p6 (loading concentrations 3, 85, and $600 \mu \mathrm{M}$ ) was equilibrated in buffer A with $50 \mathrm{mM} \mathrm{NaCl}$, unless otherwise specified. The sedimentation velocity data were analyzed with the programs XLAVEL (Beckman) and SVEDBERG (Philo, 1997). The former calculates the apparent sedimentation coefficients from the rate of movement of the solute boundary. The latter uses Faxen's approximation of the Lamm equation to fit the sedimentation profiles up to four sedimenting species. As a third method of analysis, the distribution of the apparent sedimentation coefficients, $g\left(s^{*}\right)$, was computed with the program DCDT (Stafford, 1994). The experimental sedimentation coefficients were corrected to standard conditions [water, $20^{\circ} \mathrm{C}$; see van Holde (1986)] to get the corresponding $s_{20, \mathrm{w}}$ coefficients. A gross estimation of the shape of protein p6 (monomer, dimer) was determined as follows. The translational frictional coefficient $(f)$ of protein p6 was calculated from the molecular mass and sedimentation coefficient of p6. The frictional coefficient of the equivalent hydrated sphere $\left(f_{\mathrm{o}}\right)$ was estimated using an hydration coefficient $\left(\partial_{\mathrm{w}}\right)$ of $0.3 \mathrm{~g}$ of $\mathrm{H}_{2} \mathrm{O} / \mathrm{g}$ of protein (Pessen \& Kumosinski, 1985). From these coefficients, the translational frictional ratio $\left(f / f_{\mathrm{o}}\right)$ of protein $\mathrm{p} 6$ at different states of association was determined, which allows the generation of a family of ellipsoids of revolution compatible 


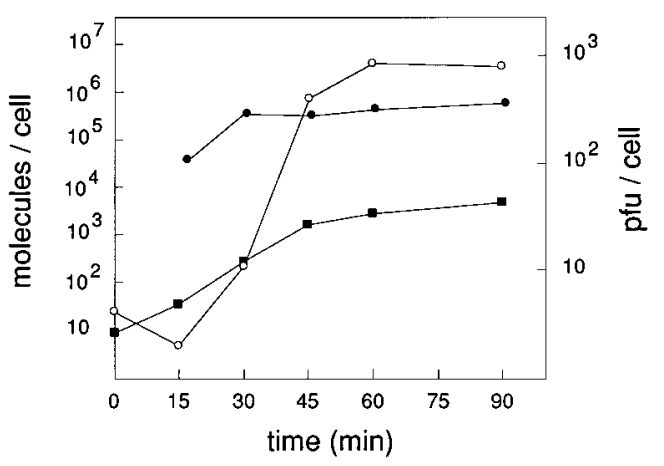

FIGURE 2: Time course accumulation of $\varnothing 29$ DNA and protein p6. B. subtilis cells were infected with $\varnothing 29$ sus 14 (1242) mutant phage, and phage development $(\bigcirc)$, amount of viral DNA (ם), and protein p6 (-) per cell was determined as described in the Materials and Methods.

with the hydrodynamic properties of the protein (Stafford \& Szent-Györgyi, 1978; Waxman et al., 1993).

\section{RESULTS AND DISCUSSION}

Determination of the in Vivo Concentration of Protein $p 6$. A previous rough estimation of the amount of protein $\mathrm{p} 6$ in vivo, using monodimensional gel electrophoresis, was about $3 \times 10^{6}$ copies per cell (Serrano et al., 1994). According to this value, assuming a cell volume of $2.6 \times 10^{-15} \mathrm{~L}$ (Luria, 1960), the protein concentration was preliminarily assessed to be in the millimolar range (Gutiérrez et al., 1994). Since protein $\mathrm{p} 6$ was not resolved from host proteins and the cell volume is dependent of growing conditions and phage infection, we have now determined more accurately the intracellular protein $\mathrm{p} 6$ concentration by calculating the amount of protein by high-resolution two-dimensional gel electrophoresis and directly measuring the cell volume under our experimental conditions.

The high amount of protein p6 synthesized in phage Ø29 infected $B$. subtilis cells allowed us to detect the protein by Coomasie staining and to determine its time course accumulation after phage infection, as well as the intracellular concentration, taking into account the number of cells and their volume. The number of cells at different times after infection was measured in a Coulter. After $90 \mathrm{~min}$ of infection, the number of cells per milliliter $[(2.75 \pm 0.03)$ $\left.\times 10^{8}\right]$ was very similar to that of uninfected cells $[(2.48 \pm$ $\left.0.02) \times 10^{8}\right]$. The cell volume was also determined by the Coulter $\left[(0.78 \pm 0.02) \times 10^{-15} \mathrm{~L}\right.$ after $90 \mathrm{~min}$ of infection]; however, since the cells have not a spherical shape, we used in the calculations a more accurate value, $(1.00 \pm 0.17) \times$ $10^{-15} \mathrm{~L}$, obtained at the same time by optical microscopy assuming the cells have an ellipsoidal shape. Figure 2 shows the time course accumulation of the intracellular protein $\mathrm{p} 6$ and viral DNA, along the phage development. Under the experimental conditions, about $10^{3}$ viable phages per infected cell was produced. Accumulation of protein p6 levels off 30 min after infection, shortly after the onset of intracellular viral production. The number of molecules of protein $\mathrm{p} 6$ per cell reached a maximum average of $(0.66 \pm 0.09) \times$ $10^{6}$, corresponding to a concentration of $1.09 \pm 0.15 \mathrm{mM}$. The estimated amount of viral DNA after 30 min of infection was about 300 molecules per cell. Since the stoichiometry of protein p6 binding to DNA is one dimer per $24 \mathrm{bp}$ (Serrano et al., 1990) and taking into account Ø29 DNA has
19285 bp (Vlcek \& Paces, 1986), 1607 molecules of protein would be required to complex entirely a single DNA molecule. Thus, at $30 \mathrm{~min}$ postinfection, the amount of intracellular protein $\mathrm{p} 6$ is about 1.4 times that required to saturate all the in vivo Ø29 DNA molecules. The number of Ø29 DNA molecules steadily increases up to $45 \mathrm{~min}$ after infection, when the available protein p6 could bind only about one third of the DNA. This figure could be underestimated, since as the viral production indicates, many DNA molecules are already encapsidated, precluding even a rough estimation of DNA molecules available for protein p6 binding.

The figures obtained for the amount of protein p6 are larger than those reported for bacterial histone-like proteins. In the case of $E$. coli $\mathrm{HU}$, it has been estimated to be about $6 \times 10^{4} \mathrm{HU}$ copies per cell allowing only $16 \%$ of the genome packaged (Drlica \& Rouviere-Yaniv, 1987). In the case of $\mathrm{H}-\mathrm{NS}$, the amount reported is even lower, $\sim 2 \times 10^{4}$ molecules per cell (Spassky et al., 1984).

Characterization of the Protein p6 Monomer-Dimer Equilibrium. Earlier analytical ultracentrifugation work (Pastrana et al., 1985) showed that protein p6 was a dimer in solution $(30,60$, and $120 \mu \mathrm{M})$, and protein p6 dimers were detected after glutaraldehyde (Freire et al., 1994) or GGH$\mathrm{Ni}$ (II) cross-linking (A. M. Abril, unpublished results). The first question to answer, the strength of the interaction between protein $\mathrm{p} 6$ monomers to form dimers, was undertaken by performing sedimentation equilibrium over a broad range of protein concentrations. Figure 3 (Panels A and B) shows that the average molecular mass $\left(M_{\mathrm{w}, \mathrm{a}}^{\mathrm{c}}\right)$ of protein $\mathrm{p} 6$ increases with protein concentration from a value corresponding to the theoretical molecular mass of the monomer (11 800) $(2 \mu \mathrm{M}$, panel A) to that of a dimer ( $95 \mu \mathrm{M}$, panel B), indicative of a monomer-dimer equilibrium. In Figure 3C, the degree of association was plotted as a function of mid-channel protein concentration. As shown, the halfsaturation of dimerization is reached at a protein p6 concentration of approximately $10^{-5} \mathrm{M}$ (estimated $K_{2} \approx 10^{5}$ $\mathrm{M}^{-1}$ ). Figure 4 shows an example of further analysis of the dimerization equilibria of protein $\mathrm{p} 6$, performed by global fitting of sedimentation equilibrium data taken at different loading protein concentrations and speeds. Again, a monomer-dimer equilibrium model fit adequately the experimental data, and the best fit parameter value for the dimerization constant $\left(K_{2}\right)$, using the Origin-NONLIN algorithm, was 2.0 $\times 10^{5} \mathrm{M}^{-1}\left(1.5 \times 10^{5}, 2.8 \times 10^{5}, 95 \%\right.$ confidence limits $)$, in agreement with the previous estimation of $K_{2}$. A similar result, $(3.5 \pm 1.5) \times 10^{5} \mathrm{M}^{-1}$, was obtained when the data were analyzed with the conservation of signal algorithm (Minton, 1994).

Effect of Temperature on the Dimerization of Protein $p 6$. The thermodynamic parameters associated with the dimerization of protein $\mathrm{p} 6$ were calculated from the temperature dependence of $K_{2}$ by means of sedimentation equilibrium. The $K_{2}$ value decreases with temperature, from 4 to $37^{\circ} \mathrm{C}$. The $K_{2}$ value at $4{ }^{\circ} \mathrm{C}$ was the same before and after incubation of protein p6 at $37^{\circ} \mathrm{C}$ (data not shown). Figure $5 \mathrm{~A}$ summarizes this analysis, in the form of a van't Hoff plot, where the natural logarithm of the association constant is plotted against the reciprocal of the absolute temperature. The standard enthalpy change $\left(\Delta H^{\circ}{ }_{\text {obs }}\right)$ on dimer formation 

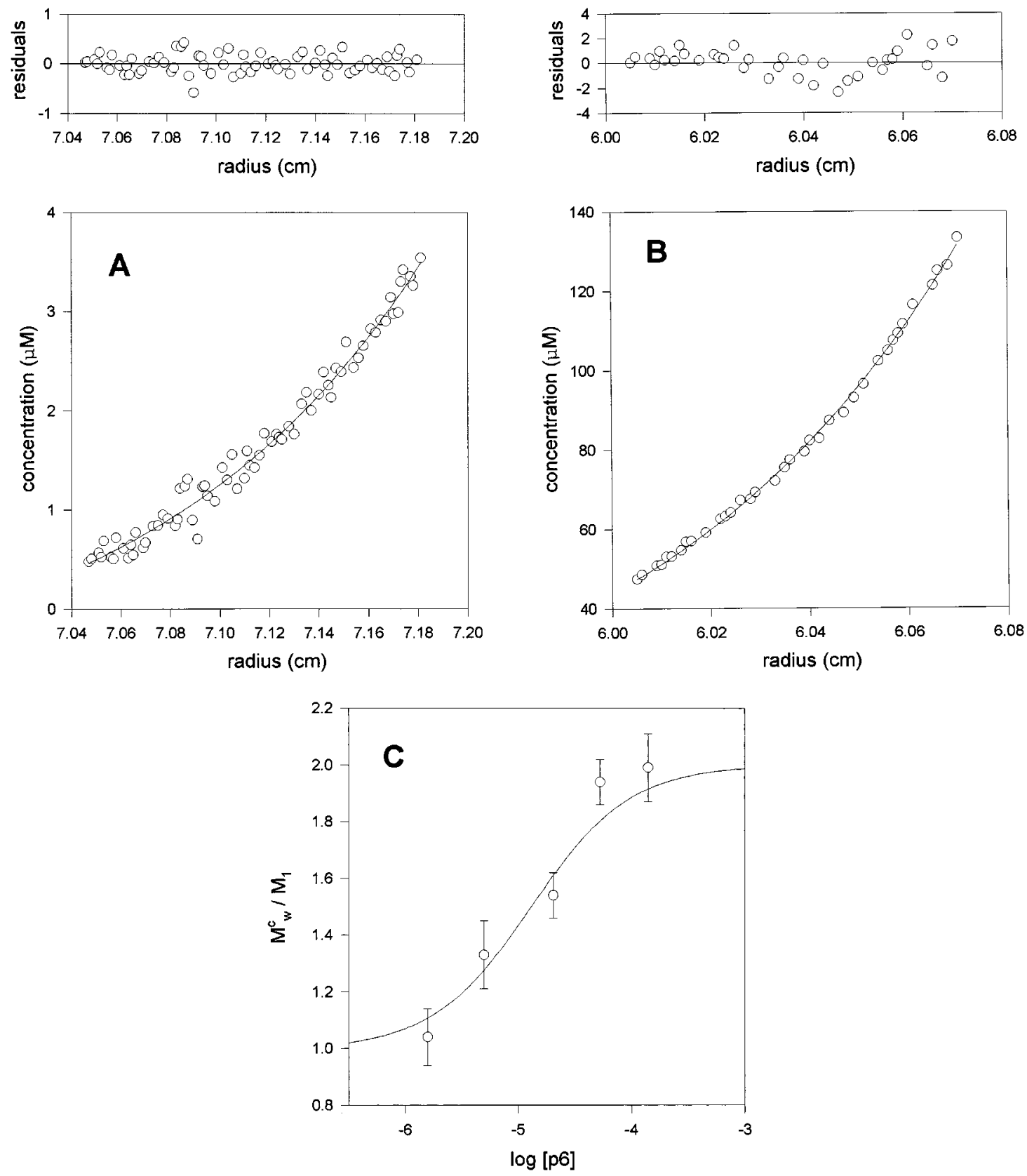

FIGURE 3: Sedimentation equilibrium analysis of protein p6. (Panel A) Sedimentation equilibrium profile of $2 \mu \mathrm{M}$ protein p6 taken in buffer A with $50 \mathrm{mM} \mathrm{NaCl}$, at $30 \mathrm{krpm}, 20^{\circ} \mathrm{C}$, as described in the Materials and Methods. The symbols represent the experimental data. The solid lines show the best fit functions for a single solute, at sedimentation equilibrium. The average molecular weight $\left(M_{\mathrm{w}, \mathrm{a}}^{\mathrm{c}}\right)$ was $11500 \pm 1000$ at this protein p6 concentration. (Panel B) The same as panel A with $95 \mu \mathrm{M}$ protein p6. In this case, $M_{\mathrm{w}, \mathrm{a}}^{\mathrm{c}}$ was $23800 \pm$ 400. (Panel C) Dependence of the degree of association $\left(M_{\mathrm{w}}^{\mathrm{c}} / M_{1}\right)$ of protein $\mathrm{p} 6$ on protein concentration. The solid line represents the best fit to a monomer-dimer equilibrium model (see text and Figure 4 for details). Error bars indicate \pm 2 SD.

can be calculated from the slope of the van't Hoff plot (Record et al., 1991):

$$
\left[\partial \ln K_{2} / \partial(1 / T)\right]_{\mathrm{p}}=-\Delta H^{\circ}{ }_{\text {obs }} / R
$$

In the case of protein p6, the van't Hoff plot is nonlinear, which would correlate with a considerable standard heat capacity change $\left(\Delta C^{\circ}\right.$,obs $)$ upon complex formation, since

$$
\Delta C_{\mathrm{p}, \mathrm{obs}}^{\circ}=\left(\partial \Delta H^{\circ}{ }_{\mathrm{obs}} / \partial T\right)_{\mathrm{p}}
$$

The data were analyzed according to the nonlinear integrated van't Hoff equation (Andreu et al., 1983; Naghibi et al., 1995):

$$
\begin{array}{r}
\ln \left(K_{2} / K_{2}^{\circ}\right)=\left[\left(\Delta H^{\circ}{ }_{\text {obs }}-T^{\circ} \Delta C_{\mathrm{p}, \mathrm{obs}}^{\circ}\right) / R\right]\left(1 / T^{\circ}-1 / T\right)+ \\
\left(\Delta C_{\mathrm{p}, \mathrm{obs}}^{\circ} / \mathrm{R}\right) \ln \left(\mathrm{T} / \mathrm{T}^{\circ}\right)
\end{array}
$$

where the superscripts indicate the corresponding thermodynamic values at a reference temperature $\left(T^{\circ}\right)$. This analysis resulted in a constant negative heat capacity change $\Delta C^{\circ}$,obs $=-0.92 \pm 0.14 \mathrm{kcal} \mathrm{mol}^{-1}$ and variable enthalpy values (at $20{ }^{\circ} \mathrm{C}, \Delta H^{\circ}{ }_{\text {obs }}=-11.3 \pm 1.9 \mathrm{kcal} \mathrm{mol}^{-1}$ ). The free energy change at each temperature was calculated directly as $\Delta G^{\circ}{ }_{\text {obs }}=-R T \ln K_{2}\left(-7.23 \pm 0.37 \mathrm{kcal} \mathrm{mol}^{-1}\right.$ at $\left.20^{\circ} \mathrm{C}\right)$ and the entropic contribution was calculated by difference 

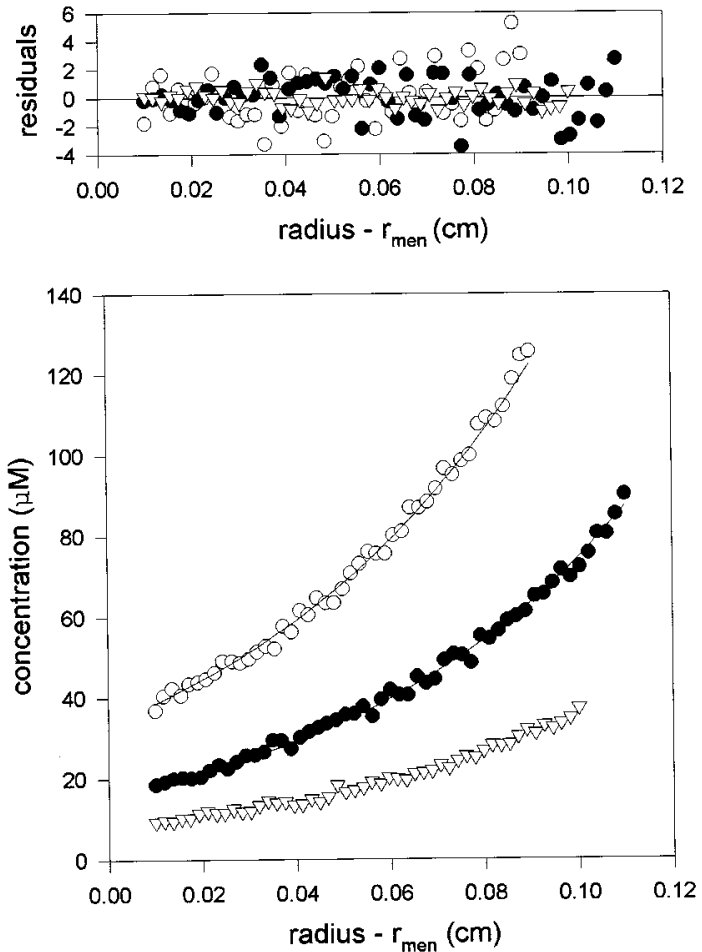

FIGURE 4: Monomer-dimer equilibrium of protein p6. The symbols show the experimental radial distribution of protein $\mathrm{p} 6$ at sedimentation equilibrium at $23 \mu \mathrm{M}(\nabla), 67 \mu \mathrm{M}(\bullet)$ and $95 \mu \mathrm{M}(\mathrm{O})$. The solid lines represent the best-fit curves of the global analysis of multiple sedimentation equilibrium data to the monomer-dimer equilibrium model (buffer A with $50 \mathrm{mM} \mathrm{NaCl}$ at $20^{\circ} \mathrm{C}$ ), described in the text $\left(\mathrm{M}_{1}\right.$ was constrained to $\left.11800 ; K_{2}=2 \times 10^{5} \mathrm{M}^{-1}\right)$. From six fitted data sets (the three previously indicated protein concentrations at $25 \mathrm{krpm}$ and $30 \mathrm{krpm})$ only three $(30 \mathrm{krpm})$ are shown. $r_{\text {men }}(95 \mu \mathrm{M})=6.01 \mathrm{~cm} ; r_{\text {men }}(67 \mu \mathrm{M})=6.53 \mathrm{~cm} ; r_{\text {men }}(23$ $\mu \mathrm{M})=7.02 \mathrm{~cm}$.

as $T \Delta S^{\circ}{ }_{\text {obs }}=\Delta H^{\circ}{ }_{\text {obs }}-\Delta G^{\circ}{ }_{\text {obs }}\left(-4.1 \pm 0.7 \mathrm{kcal} \mathrm{mol}^{-1}\right.$ at $\left.20{ }^{\circ} \mathrm{C}\right)$.

Figure 5B summarizes the temperature dependence of the observed thermodynamic functions for the dimerization of protein $\mathrm{p} 6$. The variation of the standard free energy change is relatively small in the temperature range investigated. However, as the temperature increases, there is a large decrease of both the enthalpic and entropic values contributing to this free energy change. This indicates the existence of a shift with temperature of the thermodynamic forces involved in protein $\mathrm{p} 6$ dimer formation: at low temperature it is an entropically driven process, which becomes enthalpically driven as temperature raises.

The negative values obtained for $\Delta H^{\circ}$ obs and $\Delta S^{\circ}{ }_{\text {obss }}$, that are common in protein associations, could be compatible with van der Waals contacts or hydrogen bonding occurring upon dimer formation (Sturtevant, 1977; Ross \& Subramanian, 1981). The negative $\Delta C_{\mathrm{p}, \mathrm{obs}}^{\circ}$ could result from the reduction in water-accessible nonpolar surface area on the protein upon complex formation (Livingstone et al., 1991).

Effect of Ionic Strength on the Self-Association of Protein p6. Preliminary data from protein $\mathrm{p} 6$ cross-linking experiments indicated that formation of oligomers higher than dimers was favored at concentrations of $\mathrm{NaCl}$ above $0.2 \mathrm{M}$ (R. Freire and A. M. Abril, unpublished results). The dependence of protein $\mathrm{p} 6$ self-association on ionic strength was tested by sedimentation equilibrium at 0.2 and $1.0 \mathrm{M}$ $\mathrm{NaCl}$, in addition to the previous one $(50 \mathrm{mM})$. Figure 6
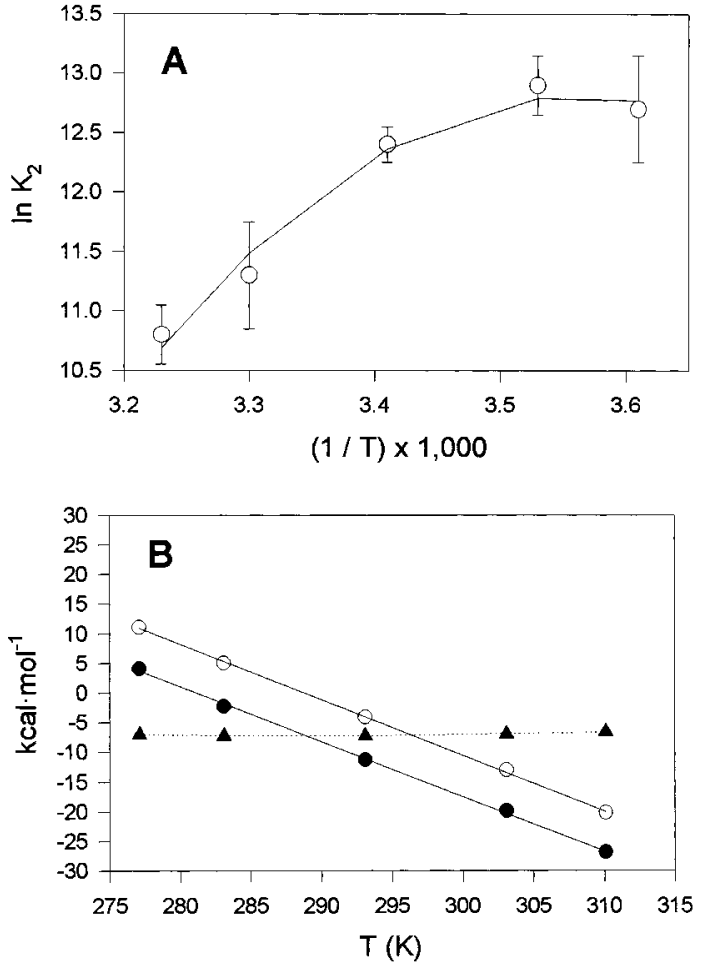

FIGURE 5: Effect of temperature on the self-association of protein p6. (Panel A) van't Hoff plot for the dimerization of protein p6 over a temperature range $4-37^{\circ} \mathrm{C}$. The open circles represent the dimerization constant determined by a global fit to a monomerdimer association model of three sedimentation equilibrium data (loading concentrations 5, 20, and $45 \mu \mathrm{M}$ ) taken at $30 \mathrm{krpm}$. The solid line is the best fit to the nonlinear integrated van't Hoff equation (see ref 3). Error bars are \pm 2 SD. (Panel B) Effect of temperature on the thermodynamic functions for the dimerization of protein p6. $\Delta H^{\circ}(\bullet), T \Delta S^{\circ}(\bigcirc)$ and $\Delta G^{\circ}(\mathbf{\Delta})$.

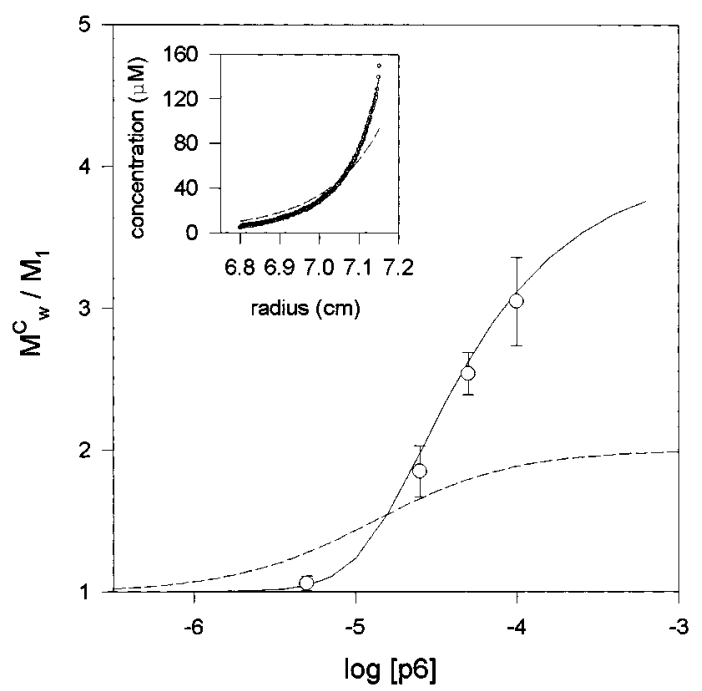

FIGURE 6: Effect of ionic strength on the self-association of protein p6. Dependence of the degree of association $\left(M_{\mathrm{w}}^{\mathrm{c}} / M_{1}\right)$ of protein p6 on $\mathrm{NaCl}$ concentration. Open circles correspond to $1 \mathrm{M} \mathrm{NaCl}$ data. The solid line shows the best fit for a monomer-dimertetramer association scheme $\left(K_{2}=1.8 \times 10^{4} \mathrm{M}^{-1} ; K_{4}=3.1 \times\right.$ $\left.10^{14} \mathrm{M}^{-3}\right)$. Error bars indicate $\pm 2 \mathrm{SD}$. The dotted line is the monomer-dimer equilibrium model at $50 \mathrm{mM} \mathrm{NaCl}$, previously described in Figure 3C. (Inset) Sedimentation equilibrium profile of protein p6 (50 $\mu \mathrm{M}$ loading concentration, $25 \mathrm{krpm}$ at $\left.20^{\circ} \mathrm{C}\right)$. Open circles are the experimental data and lines are the best fits to the association models described in the figure.

summarizes the results obtained, where the degree of oligomerization is plotted against approximate mid-channel 


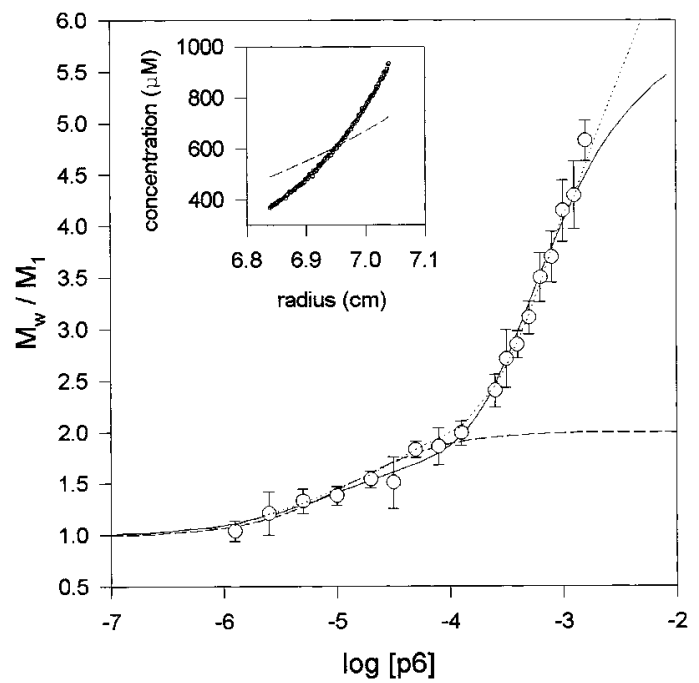

FIGURE 7: Self-association of protein $\mathrm{p} 6$ at the in vivo protein concentration. Summary of the dependence of the apparent weightaverage molecular weight on protein $\mathrm{p} 6$ concentration. Open circles represent experimental values of $M_{\mathrm{w}, \mathrm{a}}$ preaveraged as described in the text; error bars indicate $\pm 2 \mathrm{SD}$. The dashed line is the theoretical monomer-dimer equilibrium model previously described. The solid line is the best fit to a monomer-dimer-hexamer model $\left(K_{2}=\right.$ $1.1 \times 10^{5} \mathrm{M}^{-1} ; K_{2,6}=3.2 \times 10^{8} \mathrm{M}^{-2}$ ). The dotted line is the best fit to an isodesmic dimer association model $\left(K=950 \mathrm{M}^{-1}\right)$. (Inset) Radial distribution of protein p6 at sedimentation equilibrium $(0.7$ $\mathrm{mM}$ loading concentration, $15 \mathrm{krpm}$ at $20{ }^{\circ} \mathrm{C}$ ). Open circles are the experimental data and lines are the best fits to the association models described in the figure.

protein concentration for $50 \mathrm{mM}$ and $1.0 \mathrm{M} \mathrm{NaCl}$. The equilibration of protein $\mathrm{p} 6$ with $1.0 \mathrm{M} \mathrm{NaCl}$ favors the formation of higher order states of association, in agreement with the cross-linking data $(0.2 \mathrm{M} \mathrm{NaCl}$ gave an incipient effect; not shown). Global analysis of multiple sedimentation equilibrium experiments at $1 \mathrm{M} \mathrm{NaCl}$ does not support a monomer-dimer association scheme, rather a monomerdimer-tetramer model, with a $K_{2}$ value of $1.8 \times 10^{4} \mathrm{M}^{-1}$ $\left(1.0 \times 10^{4}, 2.9 \times 10^{4} ; 95 \%\right.$ confidence limits $)$ and $K_{4}$ equal to $3.1 \times 10^{14} \mathrm{M}^{-3}\left(0.4 \times 10^{14}, 6.4 \times 10^{14} ; 95 \%\right.$ confidence limits). The inset in Figure 6 illustrates the effect of salt concentration in a single sedimentation equilibrium gradient of protein $\mathrm{p} 6$.

The dependence of a self-association reaction on ionic strength gives qualitative information on the role of specific amino acid groups upon protein associations (Cole \& Ralston, 1992; Kim et al., 1977; Record et al., 1978). In the case of protein $\mathrm{p} 6$, the effect of salt indicates that charged residues do not seem to play a critical role in the formation of higher order states of association. A similar behavior with salt was found on the monomer-dimer equilibrium of $\alpha$-chymotrypsin (Aune et al., 1971). More recently, Koblan and Ackers (1991) showed an increase in $\lambda$ repressor dimer stability with $\mathrm{KCl}$ concentration.

Protein p6 Forms Higher Order Oligomers at the in Vivo Protein Concentrations. Since the intracellular concentration of protein $\mathrm{p} 6$ was estimated to be in the millimolar range, we have further studied by sedimentation equilibrium the self-association behavior of protein $\mathrm{p} 6$ at that concentration. Figure 7 summarizes the results of sedimentation equilibrium (in buffer A with $50 \mathrm{mM} \mathrm{NaCl}$ at $20^{\circ} \mathrm{C}$ ) as a plot of degree of association versus protein $\mathrm{p} 6$ concentration, over the whole range of protein concentrations employed in the present study. Each symbol represents the mean of all the data

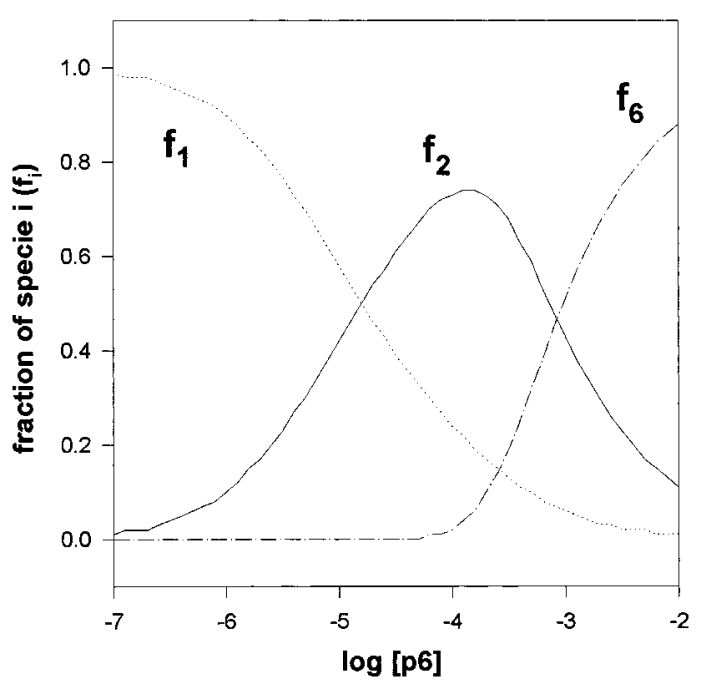

FIGURE 8: Predicted fractional distribution of protein p6 species, calculated from the best fit parameter values of the monomerdimer-hexamer model described in the text (see also Figure 7).

averaged over $\pm 0.1 \log$ unit on the concentration axis. Also plotted in the same figure are curves representing the dependence of the degree of association upon protein concentration calculated using three different models of association. The first one (dashed line) is based on the previously described monomer-dimer equilibrium model, and it is shown only for illustrative purposes, to indicate the disagreement between the experimental data and the calculated function above $\sim 0.1 \mathrm{mM}$ protein $\mathrm{p} 6$ concentration. The second calculated curve (solid line) is in reasonably good agreement with the data and was generated from the best fit parameter values of a monomer-dimer-hexamer association scheme, with a dimerization constant in the same range as the one previously found for the monomer-dimer equilibrium at low protein concentration $\left[K_{2}=(1.1 \pm 0.5) \times 10^{5} \mathrm{M}^{-1}\right.$, $\left.K_{2,6}=(3.2 \pm 1.1) \times 10^{8} \mathrm{M}^{-2}\right]$. Because the $M_{\mathrm{w}, \mathrm{a}}$ does not reach saturation at the highest protein $\mathrm{p} 6$ concentrations, the data do not exclude the formation of oligomeric structures capable of further growth, or even an isodesmic type of association (Adams \& Lewis, 1968) from the protein p6 dimer, in which the equilibrium constants for incorporation of protein dimers to the oligomer are identical. In fact, the third model (dotted line) is an isodesmic association of the dimer $\left(K=950 \pm 60 \mathrm{M}^{-1}\right)$. Experimental limitations preclude to discriminate between second and third models since we cannot go higher in protein concentration, due to the optical capabilities of the analytical ultracentrifuge. Figure 8 shows the fractional distribution of protein p6 species plotted as a function of protein concentration to illustrate the self-association scheme of protein p6. We found no evidence of nonideal behavior throughout this work, according to the residual distribution of the best fit models for the sedimentation equilibrium gradients. Moreover, including a reasonably large nonideality term in the $M_{\mathrm{w}}$ versus concentration data [based upon Chatelier and Minton (1987)] did not change the stoichiometry of the best-fit model or even significantly alter the best fit values of the association constant with respect to those obtained ignoring nonideality.

Histone-like proteins seem to have a similar behavior. Using cross-linking reagents, HU- $\alpha$ monomers are predominant at protein concentrations about $50 \mathrm{nM}$, while the predominant form is dimeric at $50 \mu \mathrm{M}$, and from $100 \mu \mathrm{M}$ (the estimated in vivo concentration), the amount of dimers 


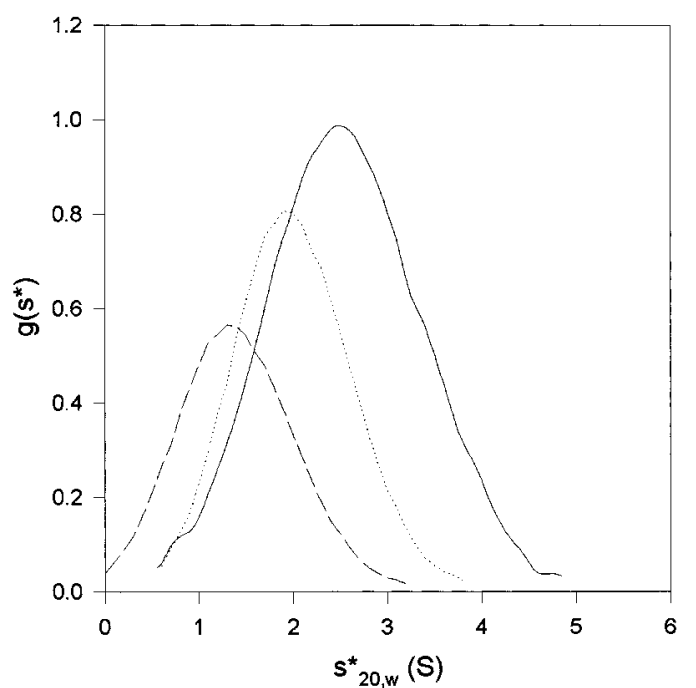

FIGURE 9: Distribution of the apparent sedimentation coefficients taken in buffer A with $50 \mathrm{mM} \mathrm{NaCl}$ at $60 \mathrm{krpm}$ and $20^{\circ} \mathrm{C}$ at three different protein p6 concentrations: $3 \mu \mathrm{M}$ (dashed line), $85 \mu \mathrm{M}$ (dotted line) and $600 \mu \mathrm{M}$ (solid line).

Table 1: Average Molecular Weights $\left(M_{\mathrm{w}, \mathrm{a}}^{\mathrm{c}}\right)$, Sedimentation Coefficients $\left(s_{20, \mathrm{w}}\right)$, and Frictional Coefficient Ratios $\left(f / f_{0}\right)$ of Protein p6

\begin{tabular}{lccc}
\hline protein p6 & \multicolumn{1}{c}{$M_{\mathrm{w}, \mathrm{a}}^{\mathrm{c}}$} & $s_{20, \mathrm{w}}$ & $f / f_{0}{ }^{a}$ \\
\hline monomer & $11500 \pm 900$ & $1.4 \pm 0.1$ & $1.15 \pm 0.08$ \\
dimer & $23800 \pm 400$ & $2.0 \pm 0.1$ & $1.30 \pm 0.07$ \\
tetramer $^{b}$ & $46200 \pm 1400$ & $2.6 \pm 0.2$ & \\
\hline
\end{tabular}

${ }^{a}$ Assuming $\partial w 0.3 \mathrm{~g}$ of $\mathrm{H}_{2} \mathrm{O} / \mathrm{g}$ of protein. ${ }^{b}$ Average value.

decreases as the amount of tetramers and larger aggregates increases (Losso et al., 1986). A similar result was obtained by gel-filtration analysis of $\mathrm{H}-\mathrm{NS}$, indicating that this protein forms a dimer as a structural unit in solution, and undergoes oligomerization, depending on its concentration; for instance, tetramers (and hexamers in some mutants) were predominant at $10 \mu \mathrm{M}$, but neither trimers nor odd-numbered oligomers could be detected (Ueguchi et al., 1996). More recently, H-NS mutants have been described with impaired capacity to oligomerize both in vitro and in vivo (Spurio et al., 1997).

Sedimentation Velocity. Sedimentation velocity profiles of protein p6 at two protein concentrations which essentially correspond to monomer and dimer protein p6 (3 and $85 \mu \mathrm{M}$, respectively; see figure 8) revealed an apparent single boundary in each case, with a higher $s$ value as protein p6 concentration increases (Figure 9). In both cases, the data are well fitted by means of the program SVEDBERG with a single sedimenting species (not shown), with $s_{20, \mathrm{w}}$ of 1.4 and $2.0 \mathrm{~S}$ for monomer and dimer protein $\mathrm{p} 6$, respectively (Table 1). These values agree, within experimental error, with those obtained with the program XLAVEL, and correspond to the peak position in the $g(s)$ profiles determined with the program DCDT (Figure 9). In the $85 \mu \mathrm{M}$ sample (predominantly protein p6 dimer), there was no significant improvement in the best fit parameter obtained with SVEDBERG if a second sedimenting species is introduced. These sedimentation coefficient values are compatible with a translational frictional ratios $\left(f / f_{0}\right)$ of 1.15 and 1.30 , respectively (Table 1), consistent with axial ratios for a prolate ellipsoid of 5.8 and 10.8, respectively. Therefore, the global hydrodynamic behavior of monomer and dimer protein p6 slightly deviates from the one corresponding to a rigid spherical particle (Teller, 1973; Waxman et al., 1993). A third protein concentration, corresponding to protein p6 oligomers $(0.6 \mathrm{mM})$ was also analyzed. This sample has a whole-cell average molecular weight of 46200 $\left(M_{1}=11800\right)$ and sedimenting species model. The best fit parameters corresponded to a 1:1 mixture of two particles with $s_{20, w}$ values of 1.9 and 3.3, respectively; the first can be identified with the dimer of protein p6 the latter has an apparent $\mathrm{s}$ value intermediate between those corresponding to tetramer and hexamer protein p6 (not shown). The complexity of this equilibrium mixture, together with the uncertainties in the shape of the oligomers species, makes difficult the discrimination between models of higher order self-association of protein p6 and precludes a more rigorous hydrodynamic analysis.

\section{CONCLUDING REMARKS}

The present study demonstrates that protein p6, in the absence of DNA, self-associates in solution. Furthermore, at physiological concentrations, protein p6 is capable of oligomerization from a preformed dimer. The oligomer formation of protein $\mathrm{p} 6$ should be enhanced in vivo due to excluded volume effects in a crowded media (Zimmerman \& Minton, 1993). The monomer-dimer-oligomer association would suggest the existence of two protein-protein interaction domains, one for monomers and the other for dimers. In agreement with this, cross-linking studies have shown that a deletion mutant of protein p6 that forms dimers is impaired in oligomerization (A. M. Abril, unpublished results). Taking into account the model proposed for the structure of protein p6-DNA complexes (Figure 1, Serrano et al., 1993), the biological problem posed is how to assemble the nucleoprotein structure to maintain this configuration. From the results obtained in this study, we speculate that protein $\mathrm{p} 6$ could behave as a scaffolding protein on which DNA folds.

\section{ACKNOWLEDGMENT}

We are very grateful to J. M. Lázaro for the purification of protein p6, J. F. Santarén for his help in the twodimensional gel electrophoresis, M. A. de Pedro for his assistance with the measurements of number and volume of cells, and B. Carrasco and J. García de la Torre for the preliminary bead modeling analysis. We also like to thank A. P. Minton for his advices in the self-association analysis and R. Giraldo for useful discussions.

\section{REFERENCES}

Adams, E. T., Jr., \& Lewis, M. S. (1968) Biochemistry 7, 10441053.

Andreu, J. M., Wagenknecht, T., \& Timasheff, S. N. (1983) Biochemistry 22, 1556-1566.

Atlung, T., \& Ingmer, H. (1997) Mol. Microbiol. 24, 7-17.

Aune, K. C., Goldsmith, L. C., \& Timasheef, S. N. (1971) Biochemistry 10, 1617-1622.

Barthelemy, I., Mellado, R. P., \& Salas, M. (1989) J. Virol. 63, 460-462.

Bravo, A., Hermoso, J. M., \& Salas, M. (1994) Mol. Gen. Genet. 245, 529-536.

Carrascosa, J. L., Camacho, A., Moreno, F., Jiménez, F., Mellado, R. P., Viñuela, E., \& Salas, M. (1976) Eur. J. Biochem. 66, 229241.

Chatelier, R. C., \& Minton, A. P. (1987) Biopolymers 26, 507524. 
Cole, N., \& Ralston, G. B. (1992) Biochim. Biophys. Acta 1121, 23-30.

Drlica, K., \& Rouviere-Yaniv, J. (1987) Microbiol. Rev. 51, 301319.

Echols, H. (1990) J. Biol. Chem. 265, 14697-14700.

Freire, R., Salas, M., \& Hermoso, J. M. (1994) EMBO J. 13, 43534360.

García de la Torre, J., \& Bloomfield, V. A. (1981) Q. Rev. Biophys. $14,81-139$.

García de la Torre, J., Navarro, S., López Martínez, M. C., Díaz, F. G., \& López Cascales, J. J. (1994) Biophys. J. 67, 530-531.

Gutiérrez, C., Freire, R., Salas, M., \& Hermoso, J. M. (1994) EMBO J. 13, 269-276.

Johnson, M. L., Correia, J. J., Yphantis, D. A., \& Halvorson, H. R. (1981) Biophys. J. 36, 575-588.

Kim, H., Deonier, R. C., \& Williams, J. W. (1977) Chem. Rev. 77, 659-690.

Koblan, K. S., \& Ackers, G. K. (1991) Biochemistry 30, 78177821.

Laue, T. M., Shah, B. D., Ridgeway, T. M., \& Pelletier, S. L. (1992) in Analytical Ultracentrifugation in Biochemistry and Polymer Science (Harding, S. E., Rowe, A. J., \& Horton, J. C., Eds.) pp 90-125, Royal Society of Chemistry, Cambridge.

Livingstone, J. R., Spolar, R. S., \& Record, M. T., Jr. (1991) Biochemistry 30, 4237-4244.

Losso, M. A., Pawlik, R. T., Canonaco, M. A., \& Gualerzi, C. (1986) Eur. J. Biochem. 155, 27-32.

Luria, S. E. (1960) in The Bacteria (Gunsalus, I. C., \& Stainer, R. Y., Eds.) p 9, Academic Press, New York and London.

Mellado, R. P., Viñuela, E., \& Salas, M. (1976) Eur. J. Biochem. $65,213-223$.

Minton, A. P. (1994) in Modern Analytical Ultracentrifugation (Schuster, T. M., \& Laue, T. M., Eds) pp 81-93, Birkhauser, Boston, MA.

Moreno, F., Camacho, A., Viñuela, E., \& Salas, M. (1974) Virology $62,1-16$.

Muramatsu, N., \& Minton, A. P. (1989) J. Mol. Recognit. 1, 166171.

Murray, C. L., \& Rabinowitz, J. C. (1982) J. Biol. Chem. 257, 1053-1062.

Naghibi, H., Tamura, A., \& Sturtevant, J. M. (1995) Proc. Natl. Acad. Sci. U.S.A. 92, 5597-5599.

Pastrana, R., Lázaro, J. M., Blanco, L., García, J. A., Méndez, E., \& Salas, M. (1985) Nucleic Acids Res. 13, 3083-3100.

Perkins, S. J. (1986) Eur. J. Biochem. 157, 169-190.

Pessen, H., \& Kumosinski, T. F. (1985) Methods Enzymol. 117, 219-255.
Philo, J. (1997) Biophys. J. 72, 435-444.

Record, M. T., Jr., Anderson, C. F., \& Lohman, T. M. (1978) $Q$. Rev. Biophys. 11, 103-178.

Record, M. T., Jr., Ha, J.-H., \& Fisher, M. A. (1991) Methods Enzymol. 208, 291-343.

Ross, P. D., \& Subramanian, S. (1981) Biochemistry 20, 30963102.

Santarén, J. F., Assiego, R., \& García-Bellido, A. (1993) Roux's Arch. Dev. Biol. 203, 131-139.

Serrano, M., Gutiérrez, J., Prieto, I., Hermoso, J. M., \& Salas, M. (1989) EMBO J. 8, 1879-1885.

Serrano, M., Salas, M., \& Hermoso, J. M. (1990) Science 248, 1012-1016.

Serrano, M., Gutiérrez, C., Salas, M., \& Hermoso, J. M. (1993) J. Mol. Biol. 230, 248-259.

Serrano, M., Gutierrez, C., Freire, R., Bravo, A., Salas, M., \& Hermoso, J. M. (1994) Biochimie 76, 981-991.

Spassky, A., Rimsky, S., Garreau, H., \& Buc, H. (1984) Nucleic Acids Res. 12, 5321-5340.

Spurio, R., Falconi, M., Brandi, A., Pon, C. L., \& Gualerzi, C. O. (1997) EMBO J. 16, 1795-1805.

Stafford, W. F. (1994) Methods Enzymol. 240, 478-501.

Stafford, W. F., III, \& Szent-Györgyi, A. G. (1978) Biochemistry 17, 607-614.

Sturtevant, J. M. (1977) Proc. Natl. Acad. Sci. U.S.A. 74, 22362240.

Teller, D. C. (1973) Method Enzymol. 27, 346-441.

Ueguchi, C., Suzuki, T., Yoshida, T., Tanaka, K., \& Mizuno, T. (1996) J. Mol. Biol. 263, 149-162.

Ussery, D. W., Hinton, J. C. D., Jordi, B. J. A. M., Granum, P. E., Seirafi, A., Stephen, R. J., Tupper, A. E., Berridge, G., Sidebotham, J. M., \& Higgins, C. F. (1994) Biochimie 76, 968980 .

van Holde, K. E. (1986) Physical Biochemistry, pp 3-23, Prentice Hall Inc., Englewood Cliffs, NJ.

Vlcek, C., \& Paces, V. (1986) Gene 46, 215-225.

Waxman, E., Laws, W. R., Laue, T. M., Nemerson, Y., \& Ross, J. A. B. (1993) Biochemistry 32, 3005-3012.

Whiteley, H. R., Ramey, W. D., Spiegelman, G. B., \& Holder, R. D. (1986) Virology 155, 392-401.

Zimmerman, S. B., \& Minton, A. P. (1993) Annu. Rev. Biophys. Biomol. Struct. 22, 27-65.

BI970994E 